\title{
Prolonged administration of secoisolariciresinol diglycoside increases lignan excretion and alters lignan tissue distribution in adult male and female rats
}

\author{
Niina M. Saarinen ${ }^{1,2}$ and Lilian U. Thompson ${ }^{1 *}$ \\ ${ }^{1}$ Department of Nutritional Sciences, Faculty of Medicine, University of Toronto, 150 College Street, Toronto, \\ ON, Canada M5S $3 E 2$ \\ ${ }^{2}$ Functional Foods Forum, University of Turku, FI-20014 Turku, Finland
}

(Received 12 October 2009 - Revised 16 February 2010 - Accepted 12 March 2010 - First published online 14 April 2010)

Limited information is available on lignan metabolism and tissue distribution between sexes and the effects of prolonged lignan exposure on tissue concentrations. In the present study, excretion and tissue distribution of lignans were compared after $1 \mathrm{~d}$ and $7 \mathrm{~d}$ administration of flaxseed lignan secoisolariciresinol diglycoside (SDG) in male and female rats. Sprague-Dawley rats were daily gavaged per os with ${ }^{3} \mathrm{H}-\mathrm{SDG}(3.7 \mathrm{kBq} / \mathrm{g}$ body weight (bwt)) and unlabelled SDG $(5 \cdot 3 \mu \mathrm{g} / \mathrm{g}$ bwt). Urine, faeces, serum and tissues (liver, kidneys, bladder, spleen, lungs, brain, thymus, heart, muscle, adipose, mammary gland, ovaries, vagina, uterus, testis, seminal vesicles, coagulating glands and ventral prostate) were collected at 0,12 and $24 \mathrm{~h}$ after a single lignan dose or after the last dose of $7 \mathrm{~d}$ exposure. The sample total lignan content was measured as radioactivity by liquid scintillation counting. In both sexes, majority of radioactivity was excreted in faeces $(40-83 \%)$ and urine $(1 \cdot 2-5 \cdot 2 \%)$. ${ }^{3} \mathrm{H}-\mathrm{SDG}$ administration increased radioactivity in all tissues at all time points, and the levels were further increased after prolonged SDG exposure. Liver contained majority of the tissue lignans (48-56\%) in both sexes after both exposure regimens. After prolonged SDG exposure, the serum lignan concentrations had reached a plateau which was approximately 4-fold of that of acute exposure, whereas in both sexes, concentrations in skin and kidneys still increased, indicating tissue accumulation. After prolonged exposure, females had higher lignan concentrations in heart and thymus at all time points, demonstrating sex-related differences in lignan tissue distribution and the possibility for sex-specific treatment responses. These findings facilitate identification of target tissues for local lignan actions in vivo.

Lignans: Secoisolariciresinol diglycoside: Tissue distribution

Secoisolariciresinol diglycoside (SDG) is a common lignan found in foods, and especially flaxseed and flaxseed-containing foods are rich in $\mathrm{SDG}^{(1,2)}$. Ingested SDG is metabolised to enterolignans such as enterodiol and enterolactone in both rats and human subjects ${ }^{(3-5)}$. Epidemiological evidence suggests that consumption of diet rich in lignans may decrease the risk of some chronic diseases such as cancer at multiple sites including breast ${ }^{(6-8)}$, prostate ${ }^{(9)}$, thyroid ${ }^{(10)}$, glioma ${ }^{(11)}$ and stomach ${ }^{(12)}$. In experimental animal models, ingested purified SDG has been shown to inhibit mammary, skin and colon cancers ${ }^{(13)}$. In postmenopausal women with newly diagnosed breast cancer, flaxseed ingestion before surgical removal of the tumour increased apoptotic index and decreased c-erB2 score of the cancer tissue ${ }^{(14)}$. Accordingly, in prostate cancer patients, flaxseed consumption decreased proliferation and increased apoptotic indices of the tumours ${ }^{(15,16)}$. These pilot studies indicate the potential of flaxseed as a neoadjuvant therapy for inhibiting cancer progression in patients. In vivo studies indicate that flaxseed lignan SDG and its metabolites mediate at least part of the anticarcinogenic effects of flaxseed ${ }^{(17-21)}$.

Very little is known about the effects of prolonged lignan administration on tissue concentrations. We have shown previously that SDG metabolites are accessible to various tissues in female rats, and that prolonged SDG exposure increased the concentration of lignan metabolites in the liver and adipose tissues ${ }^{(22)}$. However, in the earlier study, the radiolabelled SDG was administered to the animals only once, either at day 1 or at day 10 after feeding the animals unlabelled SDG. It is therefore unclear if the SDG metabolites accumulated in the tissues during the feeding period. There is also a lack of studies comparing the serum and tissue distribution of lignans in males and females. One human pharmacokinetic study performed with a single dose of SDG showed a sex difference in the time to reach the maximum lignan concentration in plasma and the mean residence time ${ }^{(5)}$. We hypothesise that the SDG metabolites increase in the serum and accumulate in the tissues after prolonged exposure, and that their levels differ in males and females. Therefore, we determined the excretion and serum and tissue distributions of lignan metabolites after a single-dose and prolonged $7 \mathrm{~d}$ (one dose per day) regimen of flaxseed SDG in adult male and female rats. Identifying possible sex differences in lignan tissue distributions is important when assessing efficacy and safety of the compounds. A better understanding of SDG metabolism and lignan tissue distribution after acute

Abbreviations: i.p., intraperitoneal; s.c., subcutaneous; SDG, secoisolariciresinol diglycoside.

* Corresponding author: Lilian U. Thompson, fax +1 416978 5882, email lilian.thompson@utoronto.ca 
and prolonged exposure is needed to identify the target organs for the lignan actions in vivo, and to determine the potential effects for different consumer groups of lignancontaining foods.

\section{Materials and methods \\ ${ }^{3}$ H-labelled secoisolariciresinol diglycoside}

SDG isolated from flaxseed ${ }^{(22)}$ was labelled with ${ }^{3} \mathrm{H}$ into benzyl methylene groups of the molecule by Amersham International (Little Chalfont, Buckinghamshire, UK). Previous studies have shown that the label in this position is stable and not affected by intestinal metabolism ${ }^{(22,23)}$. The radiochemical purity of ${ }^{3} \mathrm{H}-\mathrm{SDG}$ was $98.5 \%$. The specific radioactivity of the product was $999 \mathrm{GBq} / \mathrm{mmol}$ as described previously $^{(22)}$.

\section{Animals, diets and experimental design}

Eight-week-old male ( $n$ 18) and female ( $n$ 18) SpragueDawley rats were obtained from Charles River (St Constant, PQ, Canada). An American Institute of Nutrition-93G-based diet $^{(24)}$ modified to contain $20 \%$ fat was used as a basal diet in the study. The high fat content was used to mimic a Western diet. The diet consisted of casein $(200 \mathrm{~g} / \mathrm{kg})$, L-cystine $(3 \mathrm{~g} / \mathrm{kg})$, sucrose $(100 \mathrm{~g} / \mathrm{kg})$, maize starch $(301.06 \mathrm{~g} / \mathrm{kg})$, dextrose $(99.5 \mathrm{~g} / \mathrm{kg})$, soyabean oil $(200 \mathrm{~g} / \mathrm{kg})$, $t$-butylhydroquinone $(0.04 \mathrm{~g} / \mathrm{kg})$, cellulose $(50 / \mathrm{kg})$, American Institute of Nutrition-93G mineral mix $(35 \mathrm{~g} / \mathrm{kg})$, American Institute of Nutrition-93G vitamin mix $(10 \mathrm{~g} / \mathrm{kg})$ and choline chloride $(1.4 \mathrm{mg} / \mathrm{kg})$. After 1 -week acclimatisation to highfat American Institute of Nutrition-93G diet, the rats were weighed daily, and were gavaged accordingly per os once per day with ${ }^{3} \mathrm{H}-\mathrm{SDG}(3.7 \mathrm{kBq} / \mathrm{g}$ body weight $)$ and unlabelled SDG $(5 \cdot 3 \mu \mathrm{g} / \mathrm{g}$ body weight) in $1 \mathrm{ml}$ of distilled water. Serum and tissue samples (liver, kidneys, bladder, spleen, lungs, brain, thymus, heart, muscle, interscapular subcutaneous (s.c.) and ventral intraperitoneal (i.p.) adipose) were collected from all the rats at 0,12 and $24 \mathrm{~h}$ after a single lignan dose and after the last dose of $7 \mathrm{~d}$ lignan administration (three rats per sex at each time point). The body weights of female and male rats were 214 (SE 4) and 352 (SE 4) g after $1 \mathrm{~d}$ exposure ( $n 9$ for both sexes) and were 244 (SE 4) and 419 (SE 4) $\mathrm{g}$ after $7 \mathrm{~d}$ exposure ( $n 9$ for both sexes). In rats, interscapular s.c. adipose tissue consists mainly of brown adipose, while i.p. adipose tissue is white. Additionally, testis, seminal vesicles (without secretion), coagulating glands and ventral prostate were collected from male rats, and mammary gland, ovaries, vagina and uterus were collected from female rats. The individual rat urine and faecal samples were collected from the metabolic cages. During the collection period, rats had access to water and basal diet ad libitum. The weight or volume of the collected samples was recorded, and the samples were stored at $-20^{\circ} \mathrm{C}$ until analysis.

\section{Sample preparation and liquid scintillation counting}

The radioactivity of the samples, i.e. all lignan metabolites of administered ${ }^{3} \mathrm{H}-\mathrm{SDG}$, was measured using an earlier described method ${ }^{(22,23)}$ with slight modifications. Depending on the size and the fat content of the analysed tissue, the samples were dissolved in 0.5 or $0.7 \mathrm{ml}$ of $1 \mathrm{M}$-hyamine hydroxide in methanol (9:1, v/v; Packard Bioscience B.V., Groningen, The Netherlands), and were incubated overnight in a shaking water bath at $45^{\circ} \mathrm{C}$. A sample of dissolved tissues $(50-100 \mu \mathrm{l})$, sample of faeces homogenised in distilled water $(100 \mu \mathrm{l})$, or serum and urine samples $(50 \mu \mathrm{l})$ were mixed with $5 \mathrm{ml}$ of scintillant (Cytoscint ES, ICN Biomedicals, Costa Mesa, CA, USA). Duplicate samples were counted for 5-min periods using the TRI-CARB 2900 TR liquid scintillation analyser (Packard Instrument Company, Meriden, CT, USA).

The counting efficiencies in different tissues varied from 48 (spleen) to $77 \%$ (ovaries and uterus). The results were corrected for counting efficiency, possible losses in sample preparation, and chemical and colour quenching as described previously ${ }^{(22)}$. The measured radioactivity in samples was converted to picomole equivalents of ${ }^{3} \mathrm{H}-\mathrm{SDG}$ by dividing it by the specific activity of the radioisotope. The percentage of radioactivity excreted in faeces and urine or recovered in tissues was calculated by dividing the $24 \mathrm{~h}$ total radioactivity excretion or recovery in tissues by the amount of gavaged radioactivity (the dose administered $24 \mathrm{~h}$ before sample collection) $\times 100$. Specific tissue recovery of radioactivity was also estimated as a percentage of the sum of all tissue recoveries, i.e. specific tissue picomole value divided by the sum of picomole values of all measured tissues $\times 100$.

For some of the organs with the highest recovered radioactivities, contributions of residual blood as percentage of tissue radioactivity were calculated according to the data published by Smith $^{(25)}$. The residual blood content values ( $\mathrm{ml} / \mathrm{g}$ of tissue) used for residual blood content in liver, brain, kidneys, heart and spleen were 0.182, 0.037, 0.209, 0.243 and 0.157 , respectively ${ }^{(25)}$. The proportion of serum was calculated to account for $65 \%$ of the rat blood volume ${ }^{(26)}$.

\section{Ethical approval of the study}

Animal care and all experimental procedures in the study were approved by the University of Toronto Animal Ethics Committee, and were performed according to the Guide to the Care and Use of Experimental Animals ${ }^{(27)}$.

\section{Statistical analyses}

The statistical analyses were performed using Statistica software for Windows (StatSoft, Tulsa, OK, USA). Because the distribution of the radioactivity data was normal as determined using the Shapiro-Wilk test, the differences in radioactivity content in different tissues were analysed with one-way ANOVA followed by post hoc Tukey's test. The acceptable level of significance was set at $P \leq 0.05$ for all the analyses.

\section{Results \\ Excretion of lignans into urine and faeces}

In both male and female rats, most of the radioactivity was excreted in faeces (40-83\% of the administered dose) and urine $(1 \cdot 2-5 \cdot 2 \%$ of the administered dose) during the $24 \mathrm{~h}$ period after both $1 \mathrm{~d}$ (a single dose) and $7 \mathrm{~d}$ (one dose 


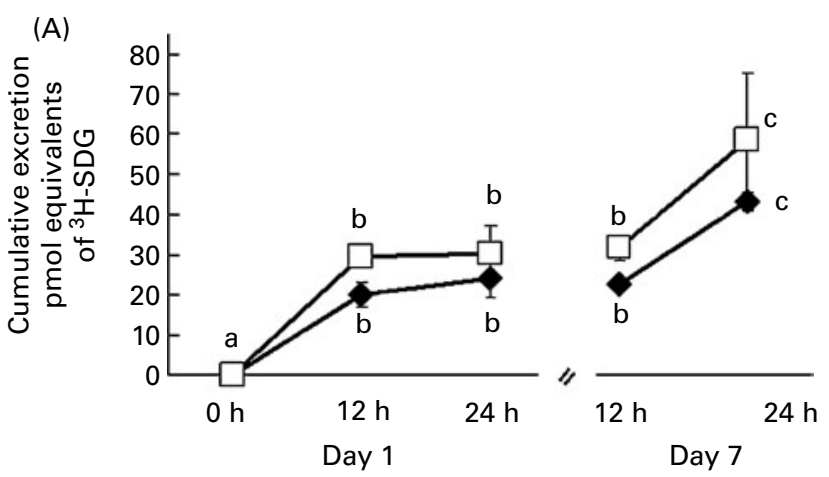

(B)

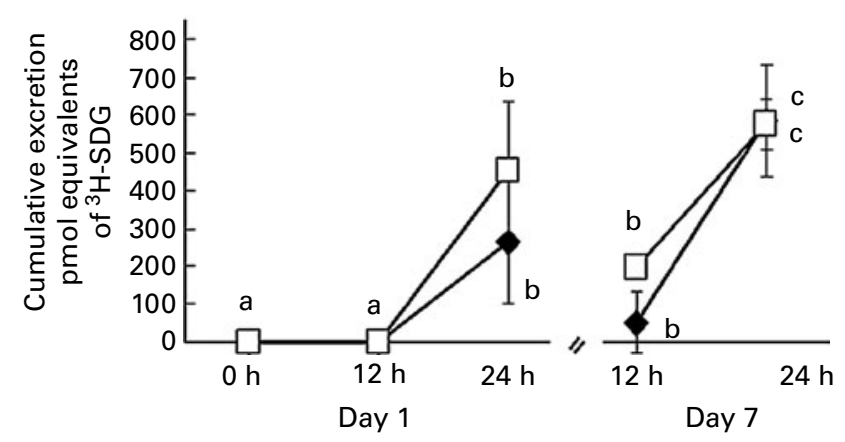

Fig. 1. Cumulative radioactivity excreted in urine (A) and faeces (B) over $24 \mathrm{~h}$ by male and female rats after a $1 \mathrm{~d}$ (single dose) and $7 \mathrm{~d}$ (one dose per day) per os administration of ${ }^{3} \mathrm{H}$-secoisolariciresinol diglycoside (SDG). The data are expressed as means with their standard errors, $n 3$ rats per time point. ${ }^{\mathrm{a}, \mathrm{b}, \mathrm{c}}$ Mean values with unlike superscript letters were significantly different $(P<0.05)$. $-\bullet-$, Females; $-\square-$, males.

per day) administration of SDG (Fig. 1). After a single dose, majority of the urinary radioactivity was excreted by the first $12 \mathrm{~h}$, but after a subchronic (7-d) exposure, urinary radioactivity excretion continued to increase for $24 \mathrm{~h}$ (Fig. 1(A)). In faeces, however, after both acute and subchronic exposure, most of the radioactivity was excreted after $12 \mathrm{~h}$ of the last dose (Fig. 1(B)). Prolonged SDG exposure significantly increased the urinary and faecal lignan excretion in both male and female rats compared with acute exposure (Fig. 1). No significant difference in urinary or faecal radioactivity excretion was observed between sexes.

\section{Serum radioactivity}

In both female and male rats, the serum ${ }^{3} \mathrm{H}$ concentrations were significantly increased $12 \mathrm{~h}$ after a single ${ }^{3} \mathrm{H}-\mathrm{SDG}$ dose, and remained constant for $24 \mathrm{~h}$ (Fig. 2). The prolonged lignan exposure increased the serum radioactivity significantly in both male and female rats, and the levels remained constant during the $24 \mathrm{~h}$ period (Fig. 2). No differences in serum radioactivity levels were measured between sexes (Fig. 2).

\section{Tissue distribution of lignans}

After a single dose of ${ }^{3} \mathrm{H}-\mathrm{SDG}$ ( $1 \mathrm{~d}$ exposure), the radioactivity concentrations were similar after 12 and $24 \mathrm{~h}$ in all the measured tissues in both sexes except in the male bladder that contained higher ${ }^{3} \mathrm{H}$ activity at $12 \mathrm{~h}$ time point (Fig. 3(A)). The $7 \mathrm{~d}$ prolonged SDG administration significantly increased the lignan concentrations in all tissues $(P<0 \cdot 05)$ compared with the $1 \mathrm{~d}$ exposure. In males and females, the highest ${ }^{3} \mathrm{H}$ tissue concentrations were measured $12 \mathrm{~h}$ after the last ${ }^{3} \mathrm{H}-\mathrm{SDG}$ dose in muscle, thymus, spleen, liver, bladder, and brain. In addition, heart in males and s.c. adipose tissue and lungs in females had the highest radioactivity at $12 \mathrm{~h}$. In males, the tissue ${ }^{3} \mathrm{H}$ concentrations were high after 12 and $24 \mathrm{~h}$ in skin, kidneys and lungs, and in females, they were high in skin and kidneys. However, the radioactivity concentration remained constant over $24 \mathrm{~h}$ in i.p. adipose tissue. The highest radioactivity concentrations were measured in female heart tissue after $7 \mathrm{~d}^{3} \mathrm{H}-\mathrm{SDG}$ exposure $(P<0.05)$, and they remained similar over the $24 \mathrm{~h}$ period (Fig. 3(B)). The lowest radioactivity concentrations were found in adipose tissues in both sexes $(P<0.05)$ (Fig. 3). In all tissues, the radioactivity concentrations were lower than those in the serum.

\section{Differences in tissue lignan distribution between males and females}

Twelve hours after a single SDG dose, male bladder contained significantly higher lignan concentrations than female bladder (Fig. 3(A)). All other sex-related differences in tissue lignan distribution were observed after $7 \mathrm{~d}$ SDG exposure, and the concentrations were higher in females than in males. Females had higher tissue lignan concentrations in thymus and heart at all time points, while in lung tissue, the lignan concentrations were higher at 0 and $12 \mathrm{~h}$ (Fig. 3(B)). In female muscle tissue, the lignan concentration was higher than that in males at $0 \mathrm{~h}$, and that in s.c. adipose tissues at $12 \mathrm{~h}$ (Fig. 3(B)). In all other measured tissues, the lignan concentrations were similar in both sexes.

\section{Lignan distribution in female and male reproductive tissues}

Similar to non-reproductive tissues, prolonged ${ }^{3} \mathrm{H}-\mathrm{SDG}$ administration significantly increased $(P<0.05)$ the radioactivity concentrations in all female (Fig. 4) and male (Fig. 5) reproductive tissues. In females, the mammary gland had the lowest and the vagina had the highest tissue lignan

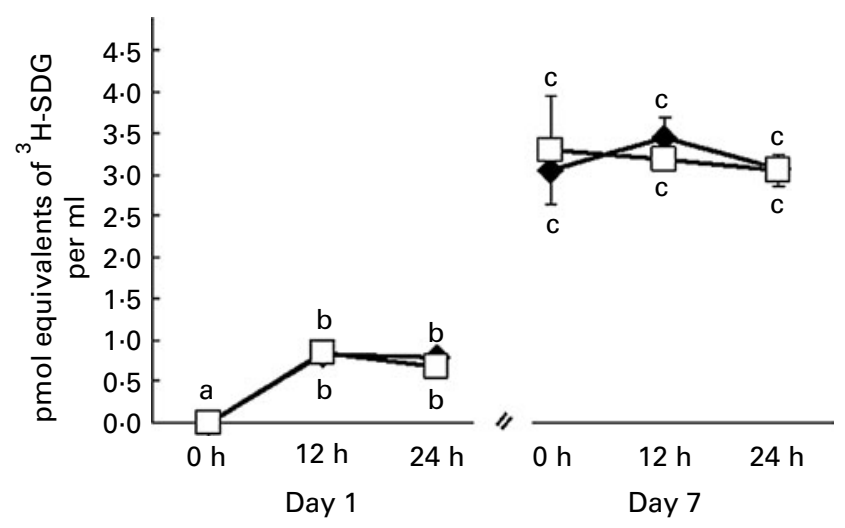

Fig. 2. Serum radioactivity concentrations at different time points over $24 \mathrm{~h}$ in male and female rats after a $1 \mathrm{~d}$ (single dose) and $7 \mathrm{~d}$ (one dose per day) per os administration of ${ }^{3} \mathrm{H}$-secoisolariciresinol diglycoside (SDG). The data are expressed as means with their standard errors, $n 3$ rats per time point. $a, b, c$ Mean values with unlike superscript letters were significantly different $(P<0.05)$. $-\bullet-$, Females; $-\square-$, males. 


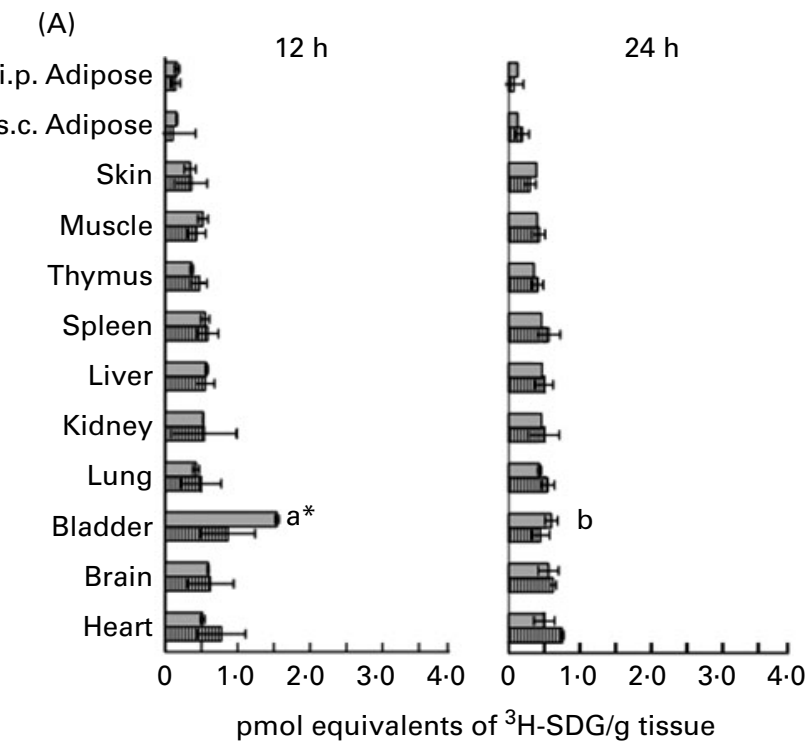

(B)

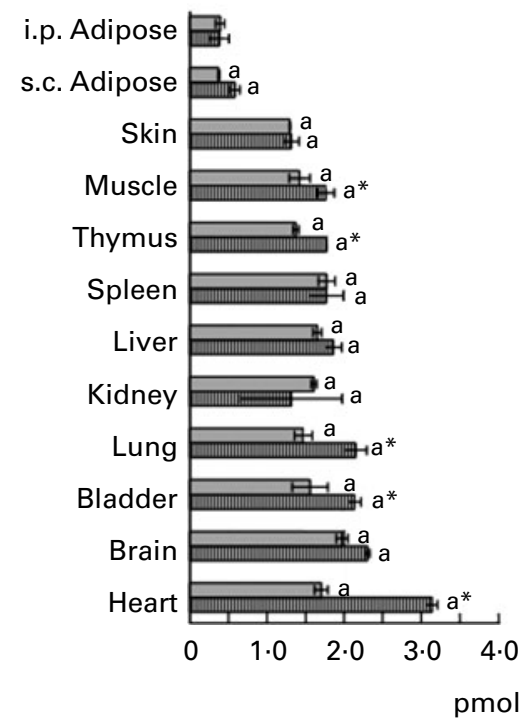

$12 \mathrm{~h}$

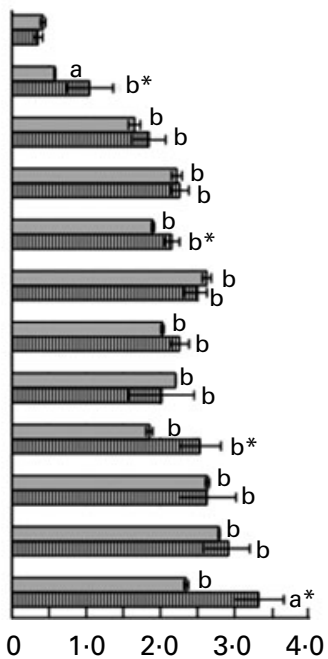

$24 \mathrm{~h}$

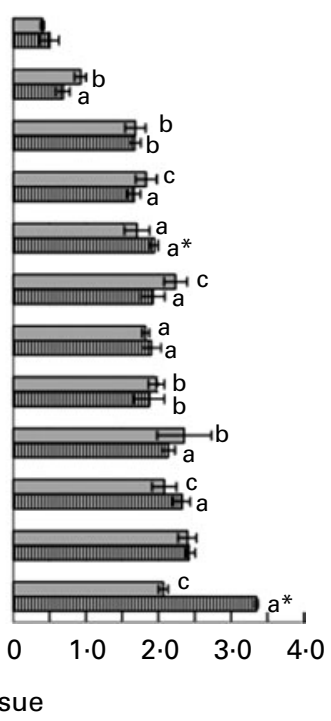

Fig. 3. Tissue radioactivity concentrations at different time points over $24 \mathrm{~h}$ in male and female rats after (A) a $1 \mathrm{~d}$ (single dose) and (B) $7 \mathrm{~d}$ (one dose per day) per os administration of ${ }^{3} \mathrm{H}$-secoisolariciresinol diglycoside (SDG). The data are expressed as means with their standard errors, $n 3$ rats per time point. ${ }^{\text {a,b,c }}$ Mean values between panels with unlike superscript letters were significantly different between time points for a tissue $(P<0.05)$. ${ }^{\star}$ Mean values were significantly different between males and females at the time point. $\square$, Males; 血, females; i.p., intraperitoneal; s.c., subcutaneous.

concentrations $(P<0.05) \quad$ (Fig. $4(\mathrm{~B}))$. After prolonged exposure, the tissue ${ }^{3} \mathrm{H}$ concentrations in ovaries, uterus and mammary gland remained similar over the $24 \mathrm{~h}$ period (Fig. 4(B)). In males, the highest radioactivity concentrations were observed in seminal vesicles $12 \mathrm{~h}$ after the last ${ }^{3} \mathrm{H}-\mathrm{SDG}$ dose of $7 \mathrm{~d}$ exposure (Fig. 5(B)). Testis, seminal vesicle and ventral prostate also had the highest radioactivity concentrations at $12 \mathrm{~h}$, and coagulating glands had the highest radioactivity concentrations at $24 \mathrm{~h}$ after the last lignan dose (Fig. 5(B)).

\section{Organ distribution of lignans}

As expected, in both sexes, liver contained majority of the recovered tissue radioactivity after both a single-dose
(53-56\% in males and $51 \%$ in females) and multiple-dose (one dose per day for $7 \mathrm{~d}$ ) administration (48-56\% in males and $50-55 \%$ in females) (Table 1). However, significant proportions of the ${ }^{3} \mathrm{H}$ activity were also recovered in brain and kidneys (8-16 and $6-11 \%$, respectively). In male reproductive organs, testes contained majority (6-11\%) of the recovered tissue radioactivity, and in females, uterus contained up to $1.2 \%$ of the recovered tissue radioactivity (Table 1).

The percentage of radioactivity recovered of the administered ${ }^{3} \mathrm{H}-\mathrm{SDG}$ dose was relatively low in all organs (Table 1). Liver contained up to $2 \cdot 1 \%$ of the administered dose, while in all other tissues, the recovery was below $1 \%$. There were no significant differences in organ weights adjusted for the body weight of 1 - and $7 \mathrm{~d}$ SDG-administered 
(A)

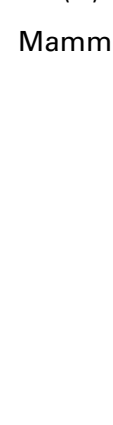

(B)

Mammary gland
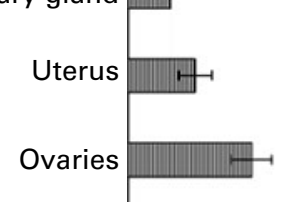

$\mathrm{Oh}$

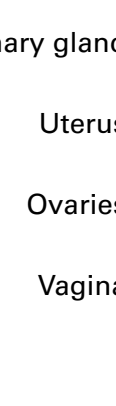

$12 \mathrm{~h}$

$24 \mathrm{~h}$

Fig. 4. Female rat tissue radioactivity concentrations at different time points over $24 \mathrm{~h}$ after (A) a $1 \mathrm{~d}$ (single dose) and (B) $7 \mathrm{~d}$ (one dose per day) per os administration of ${ }^{3} \mathrm{H}$-secoisolariciresinol diglycoside (SDG). The data are expressed as means with their standard errors, $n 3$ rats per time point. a,b Mean values between panels with unlike superscript letters were significantly different between time points for a tissue $(P<0.05)$.

male or female rats (data not shown). At necropsy, no visible changes in tissue colour or texture were observed in rats exposed to SDG compared with non-exposed animals.

In individual samples of liver, spleen, kidneys, heart and brain, residual blood accounted for $13-22,11-23,15-28$, $14-30$ and $2-5 \%$ of the measured radioactivity, respectively. No statistically significant differences in the tissue residual blood radioactivities between sexes or duration of lignan exposure were observed.

\section{Discussion}

SDG is known to be metabolised by human intestinal microbiota to secoisolariciresinol and then to enterolignans enterodiol and enterolactone ${ }^{(28,29)}$ that are found in urine, faeces and serum of SDG-exposed rats and human subjects ${ }^{(3-5,30)}$. The present study has shown for the first time increased tissue lignan concentrations in rats after prolonged (7-d) SDG exposure compared with acute (1-d) exposure regimen and lignan accumulation in specific tissues. Moreover, tissue-specific sex differences in lignan distribution were observed.

The majority of the radioactivity was excreted in urine and faeces after $1 \mathrm{~d}{ }^{3} \mathrm{H}$-SDG administration, which was further increased after prolonged lignan exposure, in agreement with previous studies ${ }^{(22,31)}$. In the present study, the urinary and faecal excretion of lignans was similar in males and females. However, while the faecal excretion was similar to, the urinary excretion of SDG-derived lignans at $24 \mathrm{~h}$ was about two times less than that in our previous study in female rats ${ }^{(22)}$, but was similar to that in male rats ${ }^{(31)}$. As in human subjects, the urinary excretion of lignans varies significantly between rats. The lignan excretion may vary few folds even between the littermates housed and treated in similar conditions and having the same basal diet (unpublished results from our laboratory). The $40 \%$ urinary excretion observed in human subjects fed SDG extract ${ }^{(5)}$ was higher partly because it was based on cumulative urinary excretion at up to $48-72 \mathrm{~h}$ instead of $24 \mathrm{~h}$. The difference in urinary excretion of SDG in rats and human subjects or pigs may be explained in part by individual differences in lignan uptake, liver metabolism and biotransformation capability of ingested lignans by gut microbiota.

In the previous study ${ }^{(22)}$, majority of faecal radioactivity was excreted during the first $12 \mathrm{~h}$ after a single ${ }^{3} \mathrm{H}-\mathrm{SDG}$ dose, while in the present study, a majority was excreted after $12 \mathrm{~h}$. This may be due to the fact that rats in the previous study were fasted before SDG administration, which may have resulted in faster faecal excretion, while rats in the present study were not fasted. In $7 \mathrm{~d}$ exposed rats, majority of lignans were excreted in urine $12-24 \mathrm{~h}$ after the last SDG dose, indicating delayed excretion compared with acute exposure when most of the lignans were excreted during the first $12 \mathrm{~h}$.

Prolonged exposure to SDG increased serum lignan levels approximately 4-fold in both male and female rats. This concurs with previous studies with flaxseed showing increased plasma and serum enterolignan concentrations in human subjects after prolonged flaxseed consumption ${ }^{(32,33)}$. In rats in the present study, the serum lignan concentrations levelled off after $7 \mathrm{~d}$ SDG administration. Accordingly, in women consuming daily $25 \mathrm{~g}$ of flaxseed, no significant differences in the plasma enterolignan levels were observed within the eighth day of flaxseed consumption ${ }^{(32)}$, indicating that approximately 1 -week exposure to flaxseed or SDG is sufficient to stabilise the serum enterolignan concentrations. Moreover, the radioactivity concentrations in serum were 
(A)

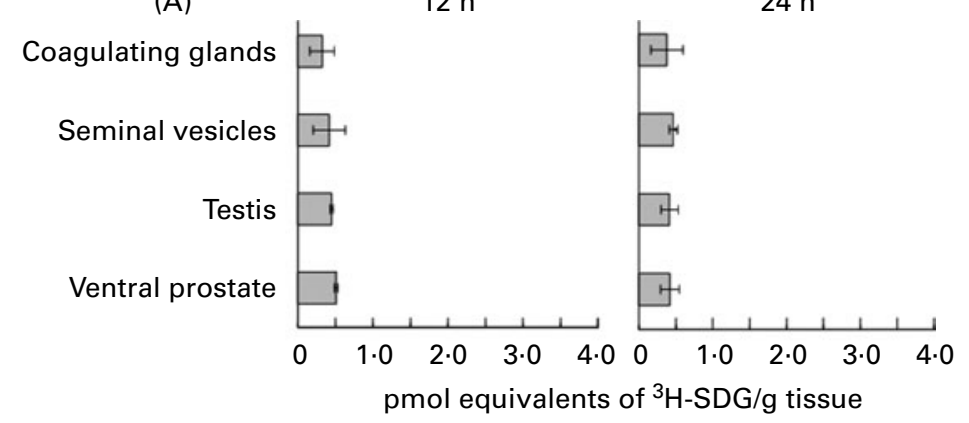

(B)

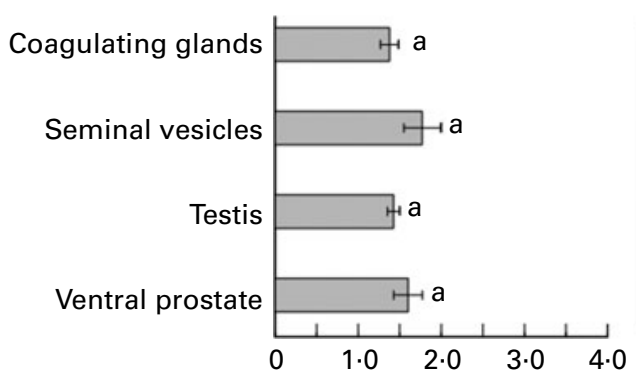

$12 \mathrm{~h}$

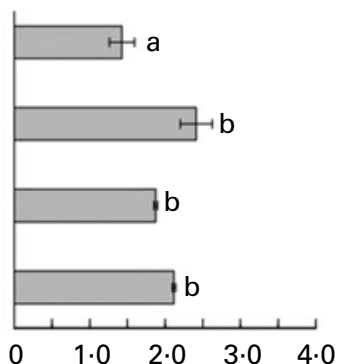

$24 \mathrm{~h}$

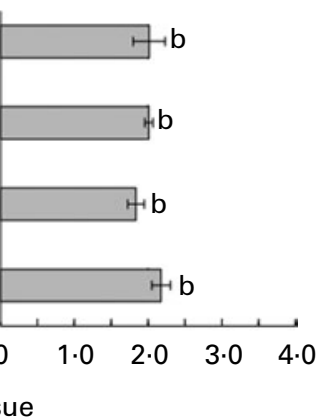

Fig. 5. Male rat tissue radioactivity concentrations at different time points over $24 \mathrm{~h}$ after (A) a $1 \mathrm{~d}$ (single dose) and (B) $7 \mathrm{~d}$ (one dose per day) per os administration of ${ }^{3} \mathrm{H}$-secoisolariciresinol diglycoside (SDG). The data are expressed as means with their standard errors, $n 3$ rats per time point. ${ }^{a, b}$ Mean values between panels with unlike superscript letters were significantly different between time points for a tissue $(P<0.05)$.

always higher than those in tissues. However, after $7 \mathrm{~d}$ ${ }^{3} \mathrm{H}-\mathrm{SDG}$ exposure, the tissue radioactivity concentrations remained elevated at $24 \mathrm{~h}$ time point compared with $0 \mathrm{~h}$ time point in skin and kidney in both sexes, and in s.c. adipose tissue, muscle, spleen, lung, brain, heart, seminal vesicles, testis and ventral prostate in males. The further increase in the tissue lignan concentrations after serum concentration has plateaued indicates slow tissue-specific lignan accumulation and the possibility for tissue concentrations higher than those in serum after long-term exposure. When sesaminol triglucoside, which like SDG can be metabolised to enterolignans, was administered to rats at a high dose $(1500 \mathrm{mg} / \mathrm{kg}$ per d), caecal and colon tissue enterolignan concentrations exceeded those of plasma ${ }^{(34)}$. Also in men, higher concentrations of enterolignans in prostate tissue than in plasma have been reported ${ }^{(35)}$. These findings by others and the accumulation of SDG-derived lignans in specific tissues in the present study suggest an active transport mechanism of lignans. Thus, serum concentrations alone do not fully reflect the concentrations in specific tissues.

The specific metabolites of ${ }^{3} \mathrm{H}-\mathrm{SDG}$ were not measured in the present study, but our previous study ${ }^{(23)}$ has shown that the radioactivity in urine after feeding ${ }^{3} \mathrm{H}-\mathrm{SDG}$ is from enterolactone $(10 \%)$, enterodiol $(55 \%)$ and secoisolariciresinol $(13 \%)$, with the rest from four unidentified metabolites. Whether the plasma and tissue levels of different lignan metabolites in the present study follow the same distribution as previously seen in urine remains to be explored.

Significant radioactivity concentrations were found in brain tissue after ${ }^{3} \mathrm{H}-\mathrm{SDG}$ administration, indicating access of the lignan metabolites across the blood-brain barrier. This concurs with our previous study in rats ${ }^{(22)}$ and athymic mice ${ }^{(36)}$. Enterolactone has been detected in the brain of sesaminol triglucoside-administered rats $^{(34)}$ and rye-fed pigs $^{(37)}$ although the concentrations were low.

The significant access of lignans into tissues such as heart, brain, lung and prostate indicates the possibility for local effects. In hypercholesterolaemic rats, dietary SDG has been shown to enhance neovascularisation of infracted myocar$\operatorname{dium}^{(38)}$. SDG and its metabolites have been shown to inhibit lipid oxidation ${ }^{(39,40)}$, which is considered an important factor for developing many neurological disorders ${ }^{(41)}$. In mice, dietary flaxseed decreased pro-oxidant-induced inflammation and lipid peroxidation in lung tissue ${ }^{(42)}$. Lignans in prostate tissue may be locally involved in reported alleviation of benign prostatic hyperplasia symptoms in $\operatorname{men}^{(43)}$ as well as in the inhibition of prostate carcinogenesis after flaxseed supplementation in mice (44) $^{(4)}$ patients ${ }^{(15,16)}$. We have shown previously in mice that SDG metabolites accumulate in human breast cancer tumours ${ }^{(36)}$, indicating increased uptake of lignans into tumour tissue, and exert antitumourigenic effect.

In rats, s.c. adipose at interscapular region contains mainly brown adipose tissue, while i.p. adipose tissue is white. We found a difference in the lignan concentrations between s.c. and i.p. adipose tissues, indicating that lignan uptake or accumulation between different adipose types may vary. Our study indicated for the first time sex differences in total lignan concentration in specific tissues. After prolonged ${ }^{3} \mathrm{H}-\mathrm{SDG}$ exposure, higher radioactivity concentrations in heart, thymus, lung, muscle and s.c. adipose tissues were observed in female rats. Indeed, the radioactivity concentrations in heart and thymus were higher in females than in males at all time points measured. A sex difference in total 
Table 1. Recovered tissue radioactivities at different time points

(Mean values with their standard errors)

\begin{tabular}{|c|c|c|c|c|c|c|c|c|c|c|}
\hline & \multicolumn{10}{|c|}{ Recovered tissue radioactivity $\%^{*}(\%$ radioactivity recovered of administered dose) } \\
\hline & \multicolumn{4}{|c|}{ Day 1} & \multicolumn{6}{|c|}{ Day 7} \\
\hline & \multicolumn{2}{|c|}{$12 \mathrm{~h}$} & \multicolumn{2}{|c|}{$24 \mathrm{~h}$} & \multicolumn{2}{|c|}{$\mathrm{Oh}$} & \multicolumn{2}{|c|}{$12 \mathrm{~h}$} & \multicolumn{2}{|c|}{$24 \mathrm{~h}$} \\
\hline & Mean & SE & Mean & SE & Mean & SE & Mean & SE & Mean & SE \\
\hline \multicolumn{11}{|l|}{ Male organs } \\
\hline Liver & $56.4(0.67)$ & $3.6(0.02)$ & $53.3(0.53)$ & $1.5(0.02)$ & $54.6(1.87)$ & $1.6(0.08)$ & $48.3(1.96)$ & $1.8(0.17)$ & $50.6(1.96)$ & $1.6(0.08)$ \\
\hline Brain & $8.5(0.10)$ & $0.5(0.00)$ & $8.9(0.09)$ & $0.6(0.00)$ & $7.9(0.27)$ & $0.4(0.02)$ & $9.2(0.37)$ & $0.4(0.01)$ & $8.5(0.34)$ & $1.2(0.06)$ \\
\hline Kidneys & $9.0(0.11)$ & $0.8(0.01)$ & $8.8(0.09)$ & $0.3(0.00)$ & $7.5(0.26)$ & $0.3(0.01)$ & $8.9(0.36)$ & $0.2(0.01)$ & $8.7(0.34)$ & $0.1(0.02)$ \\
\hline Lungs & $5.2(0.06)$ & $0.5(0.01)$ & $5.7(0.06)$ & $0.5(0.00)$ & $5.0(0.17)$ & $0.3(0.01)$ & $5.9(0.24)$ & $0.3(0.02)$ & $6.1(0.24)$ & $0.2(0.02)$ \\
\hline Heart & $4.1(0.05)$ & $0.2(0.01)$ & $4.3(0.04)$ & $0.3(0.00)$ & $4.5(0.15)$ & $0.2(0.01)$ & $4.9(0.20)$ & $0.2(0.01)$ & $4.2(0.16)$ & $0.2(0.01)$ \\
\hline Spleen & $3.7(0.04)$ & $0.3(0.01)$ & $3.5(0.03)$ & $0.6(0.01)$ & $3.3(0.11)$ & $0.4(0.01)$ & $3.9(0.16)$ & $0.0(0.01)$ & $3.3(0.13)$ & $0.2(0.01)$ \\
\hline Thymus & $1.9(0.02)$ & $0.4(0.00)$ & $2.1(0.02)$ & $0.1(0.00)$ & $2.0(0.07)$ & $0.4(0.01)$ & $2.4(0.10)$ & $0.2(0.01)$ & $2.4(0.09)$ & $0.2(0.01)$ \\
\hline Bladder & $1.4(0.02)$ & $0.3(0.00)$ & $0.5(0.01)$ & $0.1(0.00)$ & $0.4(0.01)$ & $0.0(0.00)$ & $0.5(0.02)$ & $0.1(0.00)$ & $0.5(0.02)$ & $0.0(0.00)$ \\
\hline Testes & $6.1(0.11)$ & $3.1(0.01)$ & $9.3(0.09)$ & $0.2(0.00)$ & $9.2(0.32)$ & $0.5(0.02)$ & $10.5(0.43)$ & $0.8(0.01)$ & $10.1(0.40)$ & $0.4(0.04)$ \\
\hline Seminal vesicles & $2.0(0.04)$ & $1.0(0.01)$ & $1.9(0.03)$ & $0.9(0.00)$ & $3.3(0.11)$ & $0.6(0.02)$ & $3.6(0.14)$ & $0.4(0.01)$ & $3.6(0.14)$ & $0.2(0.02)$ \\
\hline Ventral prostate & $1.3(0.02)$ & $0.0(0.00)$ & $1.2(0.01)$ & $0.2(0.00)$ & $1.9(0.06)$ & $0.2(0.01)$ & $1.3(0.05)$ & $0.1(0.00)$ & $1.5(0.06)$ & $0.1(0.00)$ \\
\hline Coagulating glands & $0.3(0.01)$ & $0.2(0.00)$ & $0.6(0.01)$ & $0.1(0.00)$ & $0.5(0.02)$ & $0.1(0.00)$ & $0.5(0.02)$ & $0.2(0.01)$ & $0.6(0.02)$ & $0.0(0.00)$ \\
\hline \multicolumn{11}{|l|}{ Female organs } \\
\hline Liver & $51.2(0.52)$ & $1.3(0.02)$ & $51.3(0.51)$ & $1.9(0.02)$ & $55.3(2.05$ & $3.2(0.17)$ & $49.7(2.04)$ & $4.0(0.16)$ & $52.2(2.01)$ & $2.5(0.16)$ \\
\hline Brain & $1.3(0.13)$ & $0.5(0.00)$ & $14.1(0.14)$ & $1.3(0.01)$ & $13.7(0.51)$ & $0.7(0.02)$ & $16 \quad(0.66)$ & $1.5(0.09)$ & $13.5(0.52)$ & $1.0(0.02)$ \\
\hline Kidneys & $10.5(0.11)$ & $0.4(0.01)$ & $9.5(0.10)$ & $0.3(0.00)$ & $6.2(0.37)$ & $3.1(0.01)$ & $8.7(0.37)$ & $1.5(0.09)$ & $9.1(0.35)$ & $1.3(0.04)$ \\
\hline Lungs & $8.7(0.90)$ & $0.8(0.01)$ & $9.7(0.10)$ & $0.4(0.00)$ & $9.1(0.34)$ & $0.1(0.03)$ & $8.6(0.36)$ & $0.1(0.03)$ & $9.1(0.35)$ & $0.5(0.01)$ \\
\hline Heart & $6.8(0.07)$ & $0.6(0.01)$ & $7.0(0.07)$ & $0.2(0.00)$ & $7.1(0.26)$ & $0.5(0.01)$ & $7.4(0.31)$ & $0.6(0.05)$ & $7.5(0.28)$ & $0.5(0.01)$ \\
\hline Spleen & $4.1(0.04)$ & $0.8(0.01)$ & $3.3(0.03)$ & $0.2(0.00)$ & $3.1(0.12)$ & $0.5(0.02)$ & $4.0(0.17)$ & $0.5(0.02)$ & $2.9(0.11)$ & $0.4(0.01)$ \\
\hline Thymus & $3.1(0.03)$ & $0.7(0.01)$ & $2.6(0.03)$ & $0.1(0.00)$ & $3.0(0.11)$ & $0.1(0.00)$ & $3.1(0.13)$ & $0.8(0.03)$ & $2.5(0.10)$ & $0.2(0.01)$ \\
\hline Bladder & $0.5(0.01)$ & $0.0(0.00)$ & $0.5(0.01)$ & $0.3(0.00)$ & $0.5(0.02)$ & $0.0(0.00)$ & $0.6(0.02)$ & $0.1(0.00)$ & $0.5(0.02)$ & $0.1(0.00)$ \\
\hline Uterus & $0.8(0.01)$ & $0.3(0.00)$ & $1.2(0.01)$ & $0.4(0.00)$ & $1.1(0.04)$ & $0.5(0.02)$ & $0.8(0.03)$ & $0.2(0.00)$ & $1.4(0.06)$ & $0.1(0.00)$ \\
\hline Ovaries & $0.5(0.01)$ & $0.0(0.00)$ & $0.6(0.01)$ & $0.0(0.00)$ & $0.5(0.02)$ & $0.1(0.00)$ & $0.6(0.02)$ & $0.0(0.00)$ & $0.6(0.02)$ & $0.0(0.00)$ \\
\hline Vagina & $0.6(0.01)$ & $0.1(0.00)$ & $0.3(0.00)$ & $0.1(0.00)$ & $0.5(0.02)$ & $0.0(0.00)$ & $0.6(0.02)$ & $0.0(0.00)$ & $0.5(0.02)$ & $0.1(0.00)$ \\
\hline
\end{tabular}

* Picomole value of specific tissue divided by the sum of picomole values of all measured tissues $\times 100 . n 3$ per time point. 
production of lignan metabolites, intestinal absorption or serum kinetics is an unlikely explanation, as no differences in serum, urine or faecal concentrations were observed between males and females. It is possible, however, that the pharmacokinetics of lignans differs between sexes in these particular tissues, and may result in diverse treatment responses between sexes. Thus, identification of those tissues with a sex difference in lignan concentrations is important when assessing their effectiveness as well as safety.

In the present study, the calculated contribution of tissue residual blood to tissue radioactivities was low, did not differ significantly between sexes and duration of exposure and did not explain the observed differences between sexes or tissue distributions.

In conclusion, prolonged ${ }^{3} \mathrm{H}-\mathrm{SDG}$ exposure increased radioactivity excretion and serum and tissue concentrations in both males and females. The significant access of SDG metabolites into tissues indicates the possibility for local effects in situ. In specific tissues, accumulation still occurred after $7 \mathrm{~d}$ exposure regimen when serum concentrations were already stabilised, indicating that serum concentrations alone do not fully reflect specific tissue concentrations. Moreover, observed sex differences in lignan tissue distribution indicate the possibility for distinct treatment responses in males and females. These findings will facilitate the identification of target tissues of lignan actions, and will help in the better understanding of the mechanisms of lignan action in vivo.

\section{Acknowledgements}

This work was supported by Natural Sciences and Engineering Research Council of Canada Grant A9995 (L. U. T.), National Technology Agency of Finland, TEKES (40285/02) and Academy of Finland (115459/06) (N. M. S.). The authors have no conflicts of interest. Both the authors designed the study and wrote the paper. The laboratory work was conducted by N. M. S.

\section{References}

1. Milder IE, Arts IC, van de Putte B, et al. (2005) Lignan contents of Dutch plant foods: a database including lariciresinol, pinoresinol, secoisolariciresinol and matairesinol. $\mathrm{Br} \mathrm{J}$ Nutr 93, 393-402.

2. Thompson LU, Boucher BA, Liu Z, et al. (2006) Phytoestrogen content of foods consumed in Canada, including isoflavones, lignans and coumestan. Nutr Cancer 54, 184-201.

3. Axelson M, Sjövall J, Gustafsson BE, et al. (1982) Origin of lignans in mammals and identification of a precursor from plants. Nature 298, 659-660.

4. Rickard SE, Orcheson LJ, Seidl MM, et al. (1996) Dosedependent production of mammalian lignans in rats and in vitro from the purified precursor secoisolariciresinol diglycoside in flaxseed. J Nutr 126, 2012-2019.

5. Kuijsten A, Arts IC, Vree TB, et al. (2005) Pharmacokinetics of enterolignans in healthy men and women consuming a single dose of secoisolariciresinol diglucoside. J Nutr 135, 795-801.

6. Torres-Sanchez L, Galvan-Portillo M, Wolff MS, et al. (2009) Dietary consumption of phytochemicals and breast cancer risk in Mexican women. Public Health Nutr 12, 825-831.

7. Cotterchio M, Boucher BA, Kreiger N, et al. (2008) Dietary phytoestrogen intake - lignans and isoflavones - and breast cancer risk (Canada). Cancer Causes Control 19, 259-272.
8. Velentzis LS, Cantwell MM, Cardwell C, et al. (2009) Lignans and breast cancer risk in pre- and post-menopausal women: meta-analyses of observational studies. $\mathrm{Br} J$ Cancer 100, $1492-1498$

9. McCann SE, Ambrosone CB, Moysich KB, et al. (2005) Intakes of selected nutrients, foods, and phytochemicals and prostate cancer risk in western New York. Nutr Cancer 53, $33-41$.

10. Horn-Ross PL, Hoggatt KJ \& Lee MM (2002) Phytoestrogens and thyroid cancer risk: the San Francisco Bay Area thyroid cancer study. Cancer Epidemiol Biomarkers Prev 11, 43-49.

11. Tedeschi-Blok N, Lee M, Sison JD, et al. (2006) Inverse association of antioxidant and phytoestrogen nutrient intake with adult glioma in the San Francisco Bay Area: a casecontrol study. BMC Cancer 6, 148.

12. Hernández-Ramírez RU, Galván-Portillo MV, Ward MH, et al. (2009) Dietary intake of polyphenols, nitrate and nitrite and gastric cancer risk in Mexico City. Int $J$ Cancer 125, $1424-1430$.

13. Thompson LU (2003) Flaxseed, lignans, and cancer. In Flaxseed in Human Nutrition, 2nd ed., pp. 194-222 [LU Thompson and SC Cunnane, editors]. Champaign, IL: AOCS Press.

14. Thompson LU, Chen JM, Li T, et al. (2005) Dietary flaxseed alters tumor biological markers in postmenopausal breast cancer. Clin Cancer Res 11, 3828-3835.

15. Demark-Wahnefried W, Price DT, Polascik TJ, et al. (2001) Pilot study of dietary fat restriction and flaxseed supplementation in men with prostate cancer before surgery: exploring the effects on hormonal levels, prostate-specific antigen, and histopathologic features. Urology 58, 47-52.

16. Demark-Wahnefried W, Polascik TJ, George SL, et al. (2008) Flaxseed supplementation (not dietary fat restriction) reduces prostate cancer proliferation rates in men presurgery. Cancer Epidemiol Biomarkers Prev 17, 3577-3587.

17. Thompson LU, Seidl MM, Rickard SE, et al. (1996) Antitumorigenic effect of a mammalian lignan precursor from flaxseed. Nutr Cancer 26, 159-165.

18. Saarinen NM, Huovinen R, Wärri A, et al. (2002) Enterolactone inhibits the growth of 7,12-dimethylbenz(a)anthracene-induced mammary carcinomas in the rat. Mol Cancer Ther 1, 869-876.

19. Wang L, Chen J \& Thompson LU (2005) The inhibitory effect of flaxseed on the growth and metastasis of estrogen receptor negative human breast cancer xenograftsis attributed to both its lignan and oil components. Int J Cancer 116, 793-798.

20. Chen J, Wang L \& Thompson LU (2006) Flaxseed and its components reduce metastasis after surgical excision of solid human breast tumor in nude mice. Cancer Lett 234, 168-175.

21. Bergman Jungeström M, Thompson LU \& Dabrosin C (2007) Flaxseed and its lignans inhibit estradiol-induced growth, angiogenesis, and secretion of vascular endothelial growth factor in human breast cancer xenografts in vivo. Clin Cancer Res 13, 1061-1067.

22. Rickard SE \& Thompson LU (1998) Chronic exposure to secoisolariciresinol diglycoside alters lignan disposition in rats. $J$ Nutr 128, 615-623.

23. Rickard SE \& Thompson LU (2000) Urinary composition and postprandial blood changes in ${ }^{3} \mathrm{H}$-secoisolariciresinol diglycoside (SDG) metabolites in rats do not differ between acute and chronic SDG treatments. J Nutr 130, 2299-2305.

24. Reeves PG, Nielsen FH \& Fahey GC Jr (1993) AIN-93 purified diets for laboratory rodents: final report of the American Institute of Nutrition ad hoc writing committee on the reformulation of the AIN-76A rodent diet. J Nutr 123, 1939-1951.

25. Smith BS (1970) A comparison of 125-I and 51-Cr for measurement of total blood volume and residual blood content of tissues 
in the rat; evidence for accumulation of $51-\mathrm{Cr}$ by tissues. Clin Chim Acta 27, 105-108.

26. Lee HB \& Blaufox MD (1985) Blood volume in the rat. $J$ Nucl Med 25, 72-76.

27. Canadian Council on Animal Care (1993) Guide to the Care and Use of Experimental Animals, vol. 1, 2nd ed. Ottawa, ON: Canadian Council on Animal Care.

28. Clavel T, Borrmann D, Braune A, et al. (2006) Occurrence and activity of human intestinal bacteria involved in the conversion of dietary lignans. Anaerobe 12, 140-147.

29. Liu Z, Saarinen NM \& Thompson LU (2006) Sesamin is one of the major precursors of mammalian lignans in sesame seed (Sesamum indicum) as observed in vitro and in rats. $J$ Nutr 136, 906-912.

30. Saarinen NM, Smeds A, Mäkelä SI, et al. (2002) Structural determinants of plant lignans for the formation of enterolactone in vivo. J Chromatogr B Analyt Technol Biomed Life Sci 777, 311-319.

31. Smeds AI, Saarinen NM, Hurmerinta TT, et al. (2004) Urinary excretion of lignans after administration of isolated plant lignans to rats: the effect of single dose and ten-day exposures. J Chromatogr B Analyt Technol Biomed Life Sci 813, 303-312.

32. Nesbitt PD, Lam Y \& Thompson LU (1999) Human metabolism of mammalian lignan precursors in raw and processed flaxseed. Am J Clin Nutr 69, 549-555.

33. Tarpila S, Aro A, Salminen I, et al. (2002) The effect of flaxseed supplementation in processed foods on serum fatty acids and enterolactone. Eur J Clin Nutr 56, 157-165.

34. Jan KC, Hwang LS \& Ho CT (2009) Tissue distribution and elimination of sesaminol triglucoside and its metabolites in rat. Mol Nutr Food Res 53, 815-825.

35. Hong SJ, Kim SI, Kwon SM, et al. (2002) Comparative study of concentration of isoflavones and lignans in plasma and prostatic tissues of normal control and benign prostatic hyperplasia. Yonsei Med J 43, 236-241.

36. Saarinen NM, Power KA, Chen J, et al. (2008) Lignans are accessible to human breast cancer xenografts in athymic mice. Nutr Cancer 60, 245-250.

37. Lærke HN, Mortensen MA, Hedemann MS, et al. (2009) Quantitative aspects of the metabolism of lignans in pigs fed fibre-enriched rye and wheat bread. Br J Nutr 102, 985-994.

38. Penumathsa SV, Koneru S, Zhan L, et al. (2008) Secoisolariciresinol diglucoside induces neovascularization-mediated cardioprotection against ischemia-reperfusion injury in hypercholesterolemic myocardium. J Mol Cell Cardiol 44, $170-179$.

39. Kitts DD, Yuan YV, Wijewickreme AN, et al. (1999) Antioxidant activity of the flaxseed lignan secoisolariciresinol diglycoside and its mammalian lignan metabolites enterodiol and enterolactone. Mol Cell Biochem 202, 91-100.

40. Hu C, Yuan YV \& Kitts DD (2007) Antioxidant activities of the flaxseed lignan secoisolariciresinol diglucoside, its aglycone secoisolariciresinol and the mammalian lignans enterodiol and enterolactone in vitro. Food Chem Toxicol 45, 2219-2227.

41. Adibhatla RM \& Hatcher JF (2008) Altered lipid metabolism in brain injury and disorders. Subcell Biochem 49, 241-268.

42. Kinniry P, Amrani Y, Vachani A, et al. (2006) Dietary flaxseed supplementation ameliorates inflammation and oxidative tissue damage in experimental models of acute lung injury in mice. J Nutr 136, 1545-1551.

43. Zhang W, Wang X, Liu Y, et al. (2008) Effects of dietary flaxseed lignan extract on symptoms of benign prostatic hyperplasia. J Med Food 11, 207-214.

44. Lin X, Gingrich JR, Bao W, et al. (2002) Effect of flaxseed supplementation on prostatic carcinoma in transgenic mice. Urology 60, 919-924. 